\title{
Industrial Engineering Higher Education in the European Area (EHEA)
}

\author{
Juan A. Marin-Garcia, Jaime Lloret \\ Universidad Politécnica de Valencia (SPAIN) \\ jamarin@,omp.upv.es; jlloret@dcom.upv.es
}

\section{Abstract:}

Purpose: We present the state of the art of industrial engineering higher education in the European area and we describe the submitted works to the special issue "Rethinking Industrial Engineering Higher Education in the European Area (EHEA)".

Design/methodology/approach: In this paper we collect the information published on industrial engineering higher education and the information provided by papers presented in the special issue.

Findings: The methodologies and approaches performed by the people teaching.

Research limitations/implications: Professors of the European area could take profit of the information provided in this paper.

Practical implications: Other lecturers could use the information provided in this paper to know more teaching methodologies or to enhance their educational methods.

Keywords: Higher Education, training and professional skills, European Higher Education Area 


\section{Introduction and related work}

Industrial engineering is the engineering discipline that deals with the plan, design, development, knowledge, improvement, implementation, installation and evaluation of the performance of complex processes or integrated systems of people, technology, and information. This engineering branch draws upon the principles and methods of engineering analysis and synthesis to specify and predict the results to be obtained. Industrial engineering tries to eliminate the waste of time money, materials, energy, equipment, and other resources. Generally the research topics are management science, operations study, and even experimental design in industry (Marin-Garcia, Garcia-Sabater, Miralles, \& Rodríguez Villalobos, 2008; Salvendy, 2001).

Depending on the field of application, Industrial Engineering can also be known as process engineering, operations management engineering, plant engineer, quality engineering, production engineering, systems engineering, industrial manager, manufacturing engineering, manufacturing systems engineering, cost and value engineering, and management engineering. However, there are specific purpose cases such as health systems engineers, financial engineers, ergonomics engineers, supply chain management and assembly lines engineers, and facilities planning engineers (Marin-Garcia, Garcia-Sabater, Perello-Marin, \& Canos-Daros, 2009). Most industrial engineers work at manufacturing companies, and many have specific areas of specialization. Some of them are consultants in the manufacturing and administrative industries (Adiguzel, 2008; Mummolo, 2007; Martínez Costa, Calvet Puig, Pons Peregort, \& Tura Solvas, 2007; Figuera Figuera, 2007).

We can find several associations of Industrial Engineers (Marin-Garcia, GarciaSabater, Miralles, \& Rodríguez Villalobos, 2008). The most important one is the Institute for Industrial Engineers (IIE, 2011). In 1988, the European Federation of productivity services founded the European Institute of Industrial Engineers (EIIE, 2011). There is also an organization for European Students of Industrial Engineering and Management (ESTIEM, 2011). They combine technological understanding with management skills. Moreover, there are others quite related, such as the American Society of Mechanical Engineers (ASME, 2011). 
Industrial Engineering degree comprises of in-depth knowledge of making and implementation of integrated systems of technology, human knowledge and material that are used in the industry (Salvendy, 2001). It should add all the issues aforementioned to the student curriculum. Moreover, it should adopt operation research techniques and methods based on an analytical foundation. The subjects of the Industrial Engineering degree should provide training in the skills needed to improve quality, safety, efficiency, effectiveness and performance (Wei, 2005; Marin-Garcia, Garcia-Sabater, Perello-Marin, \& Canos-Daros, 2009).

A list of Spanish universities that offer Industrial Engineering Degree in Spain is found in (Spain Exchange, 2011). Moreover, some European universities publish which universities of other countries offer Industrial Engineering (IIP, 2011). There is also published a list of universities that offer Industrial Engineering in U.S.A. (The Sloan Career Cornerstone Center, 2011). This last document also shows some well known list of employers of organizations that require the skills of Industrial Engineers.

Because of the wide range of application of industrial engineering, any new student must have a solid background in mathematics, science, operations management and technology, and courses in English, management, and computer and information technology (Salvendy, 2001).

Students of industrial engineering should acquire knowledge of many specific areas in every industry. They should learn extensive mathematical and methodical proficiency and usage of quantitative methods to optimize the operation of a process, system, or organization. They must know how to analyze and evaluate methods of production and point out ways to improve them. Students of industrial engineering are tasked with improving processes and finding the most effective ways to design, develop, produce, deliver or service products and meet people's needs in a variety of businesses (Aqlan, Al-Araidah, \& Al-Hawari, 2010; KorhonenYrjñnheikki, Tukiainen, \& Takala, 2007).

Students of industrial engineering should be aware of the learning curve and perform an appropriate division of tasks, and how any form of work can be split into simple types of work. They should know how learning is affected by the events, and the effect of learning on the generation of waste and the cost of production. So they could decide how a company should allocate its limited 
resources within the framework of existing physical constraints. Industrial engineers typically use computer simulations, along with mathematical tools and modeling and computational methods for system analysis, modeling, evaluation, and optimization. The development of sub-routines and calculations could be done with the computer in minutes and easily repeated with new problem criteria.

The proper level of training should be performed in Industrial engineering degree. Standards are set using people that are familiar with the job and people who have mastered the skills required to perform the job. Some learning topics must be included in the training process of industrial engineers. Some of them are how to develop good incentive plans, production methods, logistics, scheduling of work, methods for shortening queues, streamlining an operating room, distributing products worldwide, and manufacturing cheaper and more reliable products. They should be able to diagnose and correct problems in the delivery of care, and should be able to increase the productivity, controlling costs, and reducing wait times for customers (Marin-Garcia, Garcia-Sabater, Perello-Marin, \& Canos-Daros, 2009).

Globalization is one of the contextual factors most strongly influencing the way in which we understand and design today's business processes. It is a movement which also affects higher education, where national approaches are converging towards a set of models which are gradually taking root across our neighboring countries (Wei, 2005).

It is our belief that there exists today a need to maintain an open debate as to the type of higher education most appropriate in order to develop the profession of Industrial Engineering (Marin-Garcia, Garcia-Sabater, Miralles, \& Rodríguez Villalobos, 2008; Chen, Jiang, \& Hsu, 2005; Prasad \& Bhar, 2010; Tynjälä, Salminen, Sutela, Nuutinen, \& Pitkänen, 2005).

Related to this, various sources have propounded the advantages offered by considering a teamwork-based methodology with university students. On the one hand, it enables students to experiment and acquire the skills that they will need in their future jobs. On the other, teamwork used in a context of active methodologies provides deeper and more significant learning. In addition, positive effects have been shown on the academic performance of students, motivation and their attitudes towards learning. Some of these advantages have also been underscored by students, who consider group activities and active methodologies 
to be more interesting, entertaining and learning-facilitating than traditional teaching. Due to its advantages teamwork has been a major aspect of university teaching. However, although the majority of teachers propose group activities to their students, the question still remains as to what the best way is of organizing and handling student teamwork (Marin-Garcia, Martínez Gómez, \& Lloret, 2009; Lloret \& Marin-Garcia, 2008).

The aim of this special issue is to develop a clear definition of industrial engineering and industrial management higher education, not only in European context but in a global world. This can range from the professional profiles to be expected of those graduates, skills to be developed, methods to improve learning or assessment. Qualitative and quantitative approaches are encouraged. Only submissions of methodological and theoretical rigour will be considered.

Examples of topics of interest include, but are not limited to:

- Competencies and skills for Industrial Engineering, Operations Management or Industrial Management.

- Difference from other forms of engineering higher education (mechanical, chemical, manufacturing...).

- Industrial Engineering curriculum.

- Assessment methods for the Industrial Engineering and Management competencies.

- Applications and tools to improve university classes.

- Active methodologies in engineering, operations or management education.

- Collaborative learning in the higher education.

- Barriers and enablers to use teamwork with university Industrial Engineering students.

- Student workload in the new learning methodologies framework.

- Teacher workload and other limitations. 
- Strategies for university lecturer training.

The first step to be performed is to know how to search articles related to university teaching of Industrial Engineering. A good guide can be found in MarinGarcia (2011) or Medina-López et al. (2010).

In the related literature we can find several papers about how learning systems are applied to industrial engineering. Some examples include USA, China, Hong Kong, Malaysia, Chile and Spain (Singh et al., 2004; Ping, 2005; Lau \& Mak, 2005; Hassim et al, 2004; Pascual \& Utribe, 2006; Marin-Garcia and Lloret, 2008; Lassibille \& Navarro Gómez, 2008; Aqlan, Al-Araidah, \& Al-Hawari, 2010; Prasad \& Bhar, 2010; Tynjälä, Salminen, Sutela, Nuutinen, \& Pitkänen, 2005; Adiguzel, 2008).

The remainder of the paper is structured as follows. The papers selected to be published in this special issue are described in section 2 . Section 3 draws the conclusions and gives the future trends in learning methods and training systems for Industrial Engineering Higher Education.

\section{Papers selected for this Special I ssue}

In this section we summarize each paper accepted for this special issue and its main contribution.

Cristina Santandreu-Mascarell et al. presented the paper entitled "Competencies and skills for future Industrial Engineers defined in Spanish degrees". They present a review of specific degrees of Industrial Engineering implemented in Spanish universities (taken from Ministerial documents and other reference papers), in order to know the real professional profile of an Industrial Engineer and the similarities and differences between them and with ideal models. Then, they analyze the competencies and skills proposed as ideals for an Industrial Engineering degree, by identifying them in the current study plans implemented in Spanish universities, and, next, they compare them with the ones existing in real business environments. Finally, they checked the fit between them. In the new industrial engineering degree in Spain the students can choose their curricula because of the differences that exist between different degrees in different universities. 
The paper with title "Active learning in Operations Management: interactive multimedia software for teaching JIT/Lean Production" is presented by Carmen Medina-López et al. In this paper they show the development and assessment of a complex and truly interactive ICT-based teaching tool for instruction in operations management subject. In order to achieve their goal, they developed a multimedia application for Just-in-Time (JIT) / Lean Production. The students assessed the tool and compared it with traditional teaching methods. The study was carried out in a controlled environment and not in the normal on-site university teaching process. Students are in favor of the incorporation of ICT in the classes. The analysis of the application, the interface, and its easy to use, obtained very positive scores in its design and operation. Student perceptions also indicate that the application support the understanding and the learning of the concepts that are being explained and stimulate interest in the subject matter.

In the paper with title "Different applications of concept maps in Higher Education", Amparo Bes Piá et al. show different applications of concept maps in higher education, concretely in qualifications of the Polytechnic University of Valencia. They used different methodologies depending on the application of concept maps. Students consider the concept maps useful mainly to select key ideas, to achieve a comprehensive view of the lesson, and to bring up the subject. Moreover, concept maps promote the active and meaningful learning, help students to understand, follow-up, and learn subjects with a high load of contents. They can be applied as a technique to study or as a learning tool promoting reflection, analysis, and creativity. The authors state that the tool can be applied to any discipline (basics, social or applied sciences) and at any level of education.

Julio J. Garcia-Sabater et al. analyze in the paper "Practical experience in teaching inventory management with Edublogs" the edublogs tool in teaching-learning process applied to Industrial Engineering postgraduate Courses. The results of their study show that edublogs meet the expectations of both the teacher and the students. The platform used to share blogs also allowed the teacher to highlight the most important aspects for the students and link them with other topics of interest.

Building's installations project is a complex task. To address this problem, the paper “Project-Based Learning used for teaching Electrical Installations and 
Lighting Installations in Architecture", written by Alicia Martínez Antón, looks at the use of Project-Based Learning (PBL) in a subject which is taught in the Escuela de Arquitectura at the Universitat Politècnica de València in the industrial engineering field. The method set out involves cooperative learning and formative assessment as basic and complementary components of PBL. The results show that this method was particularly effective in this field in terms of motivation, improved learning outcomes, independent learning and connection with professional practice.

In the paper with title "A freshmen mentoring program at the Universitat Politècnica de València over the period 2000-2010", Xavier Barrachina et al. present a mentoring program for freshmen at the Universitat Politècnica de València. They explain how the program started, how it is organized and conducted, and which the tasks of each mentor are. In order to assess each role in the program, they report the results of a peer evaluation between mentors and mentees and they include an estimation of the time dedicated to the program by mentors and mentees. It has been obtained by asking all participants to make a peer evaluation by filling a questionnaire. The mentees are satisfied with the program and they would highly recommend other freshmen to participate in it. On the other hand, the student mentor feels more enthusiastic with the program than the teacher mentor. Moreover, student mentors think that mentees could take more profit from their participation. Finally, the teacher mentors have high expectations on the program.

\section{Conclusions and future trends}

In this paper we have reviewed the main issues to take care in the Industrial Engineering curriculum. We have also reviewed the most well know topics to be included in the industrial engineering degree. Some related work show the state of the art in learning and training methods for industrial engineering for Higher Education in the European area. Then we have shown the last educational researches, learning techniques and training methods submitted to this special issue.

In the last decades industrial engineering curriculum has incorporated the methods of operation research scientists to analyze production and service problems. These analytical methods and the advancing simulation technologies, modeling complex 
production and service systems highly support the tasks of an Industrial Engineer, so they will be included in the topics of the subjects of the Industrial Engineering degree. Better and new models to give accurate predictions about future performance will be added. So, learning and training methods should include computer simulation techniques.

Subjects should include cooperative multidisciplinary approaches in topics related with cost analysis, design production planning and control systems to coordinate activities and ensure product quality. Active learning methods will help the students learn to anticipate, recognize, and evaluate hazardous conditions as well as develop hazard control methods. Related to this, methodologies to assess the competencies acquired by students should be improved.

\section{References}

Adiguzel, O. C. (2008). An evaluation of industrial placement in engineering programmes: a case in Turkey. European J ournal of Engineering Education, 33(1), 33-43.

doi: $10.1080 / 03043790701746140$

American Society of Mechanical Engineers Website (2011). Retrieved from http://www.asme.org/

Aqlan, F., Al-Araidah, O., \& Al-Hawari, T. (2010). Quality assurance and accreditation of engineering education in J ordan. European J ournal of Engineering Education, 35(3), 311-323.

doi: $10.1080 / 03043797.2010 .483608$

Chen, C. k., Jiang, B. C., \& Hsu, K. y. (2005). An empirical study of industrial engineering and management curriculum reform in fostering students' creativity. European J ournal of Engineering Education, 30(2), 191-202.

doi: $10.1080 / 03043790500087423$

European Institute of Industrial Engineers Website (2011). Retrieved from http://www.efps.ac/eiie-c-2.html

European Students of Industrial Engineering and Management Website (2011). Retrieved from https://www.estiem.org/ 
Figuera Figuera, J. R. (2007). Análisis del pasado de la Ingeniería de Organización en España para mantener su competitividad en el futuro. Paper presented the International Conference on Industrial Engineering \& Industrial Management ClO (pp. 931-940). Madrid.

Institute for Industrial Engineers Website (2011). Retrieved from http: //www. iienet2.org/Details. aspx?id $=282$

Institutionen för Industriell Produktion, Skolan för Industriell Teknik och Management Website (2011). Retrieved from http://www.iip.kth.se/eprode/information/Spain.doc

Korhonen-Yrjñnheikki, K., Tukiainen, T., \& Takala, M. (2007). New challenging approaches to engineering education: enhancing university-industry co-operation. European J ournal of Engineering Education, 32(2), 167-179.

Lau, H, \& Mak, K. (2005). A Configurable E-Learning System for Industrial Engineering. The International journal of engineering education, 21(2), 262-276.

Lassibille, G., \& Navarro Gómez, L. (2008). Why do higher education students drop out? Evidence from Spain. Education Economics, 16(1), 89-105.

doi: 10.1080/09645290701523267

Lloret, J. \& Marin-Garcia, J. A. (2008). Comparing Novel and Stable Lecturers' Point of View when They Use University Students Working Groups in their Classrooms. WSEAS Transactions on Advances in Engineering Education, 11(5), 699-708.

Marin-Garcia, J. A., Garcia-Sabater, J. P., Miralles, C., \& Rodríguez Villalobos, A. (2008). Profile and competences of Spanish industrial engineers in the European Higher Education Area (EHEA). Journal of Industrial Engineering and Management, 1(2), 269-284.

Marin-Garcia, J. A., Garcia-Sabater, J. P., Perello-Marin, M. R., \& Canos-Daros, L. (2009). Proposal of skills for the bachelor degree of Industrial Engineering in the context of the new curriculum. Intangible Capital, 5(4), 387-406.

Marin-Garcia, J. A., Martínez Gómez, M., \& Lloret, J. (2009). Enhancing Motivation and Satisfaction of Students: Analysis of Quantitative Data in Three Subjects of 
Industrial Engineering. WSEAS Transactions on Advances in Engineering Education, 6(1), 11-21.

Marin-Garcia, J. A., \& Lloret, J. (2008). Improving Teamwork with University Engineering Students. The Effect of an Assessment Method to Prevent Shirking. WSEAS Transactions on Advances in Engineering Education, 5(1), 1-.

Marin-Garcia, J. A.. (2011). ¿Dónde se publican artículos de investigación docente relacionados con asignaturas de Ingeniería Industrial? (Where are published research articles related to university teaching of Industrial Engineering?). Working Papers on Operations Management, 2(1), 01-06.

Martínez Costa, C., Calvet Puig, D., Pons Peregort, O., \& Tura Solvas, M. (2007). Inserción laboral de las titulaciones de la subárea de tecnologías avanzadas de la producción. Paper presented at the International Conference on Industrial Engineering \& Industrial Management - ClO (pp. 985-992). Madrid.

Medina-López, C., Marin-Garcia, J. A., \& Alfalla-Luque, R. (2010). Una propuesta metodológica para la realización de búsquedas sistemáticas de bibliografía ( $A$ methodological proposal for the systematic literature review). Working Papers on Operations Management, 1(2), 13-30.

Hassim, M., Kamaruddin, M. Hamid, A., Hassan, M, Yusof, M., Hassan, S., \& Esa, M. (2004). Enhancing Learning through Cooperative Learning: UTM Experience, Conference on Engineering Education, Kuala Lumpur.

Mummolo, G. (2007). The future for industrial engineers: education and research opportunities. European J ournal of Engineering Education, 32(5), 587-598.

Pascual, R., \& Utribe, R, (2006). Experiential Learning Strategies in a Mechanical Engineering Senior Course. Sixth International Workshop on Active Learning in Engineering Education, Monterrey, Mexico.

Prasad, G., \& Bhar, C. (2010). Accreditation system for technical education programmes in India: A critical review. European Journal of Engineering Education, 35(2), 187-213.

doi: $10.1080 / 03043790903497294$ 
Salvendy, G. (2001). Handbook of industrial Engineering. Technology and operations management. New York: John Wiley \&Sons.

doi: $10.1002 / 9780470172339$

Spain Exchange Website (2011). Retrieved form

http://www.spainexchange.com/study_abroad/subjects2-en-57-ES.htm

Ping, S. (2005). The study of teaching methods for Industrial Engineering. J ournal of Guangdong University of Technology (Social Sciences Edition), 2005-S1.

The Sloan Career Cornerstone Center (2011). Industrial Engineering Overview. Retrieved from http://www.careercornerstone.org/pdf/ie/indeng.pdf

Tynjälä, P., Salminen, R. T., Sutela, T., Nuutinen, A., \& Pitkänen, S. (2005). Factors related to study success in engineering education. European Journal of Engineering Education, 30(2), 221-231.

Singh V., Khasawneh M., Bowling, S., Kaewkuekool, S., Jiang, X., \& Gramopadhye, A. K. (2004). The evaluation of alternate learning systems in an industrial engineering course: Asynchronous, synchronous and classroom. International Journal of Industrial Ergonomics, 33, 495-505.

doi: 10.1016/j.ergon.2003.12.003

Wei, J. (2005). Engineering education for a post-industrial world. Technology in Society, 27(2), 123-132.

doi: 10.1016/j.techsoc. 2005.01.001

Journal of Industrial Engineering and Management, 2011 (www.jiem.org)

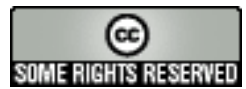

Article's contents are provided on a Attribution-Non Commercial 3.0 Creative commons license. Readers are allowed to copy, distribute and communicate article's contents, provided the author's and Journal of Industrial Engineering and Management's names are included. It must not be used for commercial purposes. To see the complete license contents, please visit http://creativecommons.org/licenses/by-nc/3.0/. 